Received 16 July 2020

Accepted 18 December 2020

Link to DOI:

10.25220/WNJ.V05.i1.0005

Journal Website: www.worldnutrijournal.org

\section{Low dietary omega- 6 to omega-3 fatty acid intake ratio enhances adiponectin level in obesity}

\author{
Helena Fabiani, ${ }^{1,2}$ Ninik Mudjihartini, ${ }^{3}$ Wiji Lestari ${ }^{1}$ \\ 1. Department of Nutrition, Faculty of Medicine, Universitas Indonesia, Dr. Cipto Mangunkusumo \\ General Hospital, Jakarta, Indonesia \\ 2. Department of Nutrition, Faculty of Medicine, Universitas Kristen Krida Wacana, Indonesia \\ 3. Department of Biochemistry and Molecular Biology, Faculty of Medicine, Universitas Indonesia, \\ Jakarta, Indonesia
}

\begin{abstract}
Every year around the world, the prevalence of obesity is increasing. Obesity and its associated diseases have become some of the most pressing health problems in developed and developing countries. In its development, adipocytes dysfunction and chronic low-grade inflammation occur in obesity will stimulate diseases at higher risk including type 2 diabetes mellitus (T2DM), atherosclerosis, hypertension, and metabolic syndrome. Western diet and sedentary lifestyle are thought to have significantly contributed to the increase in obesity recently. Diet modification is a sound method to prevent obesity and its complications. Nevertheless, the concern lies in the ratio of omega- 6 towards omega- 3 fatty acids intake, modern dietary habits induce transition of this ratio from 1-4:1 to 20:1 or higher. Omega-3 and omega- 6 are two essential fatty acids that emerge as dominant factors in obesity through adiponectin. Adiponectin refers to a protein hormone conceived by adipocytes to prevent obesity and its subsequent complications by increasing insulin sensitivity, fatty acid oxidation, anti-inflammatory, and antiaterogenic. This study is a literature study with sources from journals and textbooks in the last ten years. This study aims to determine the role of fatty acids in omega- 6 towards those within omega- 3 by using adiponectin as the indicator of advancement to obesity and its underlying diseases. Several studies that examined the ratio of omega- 6 to omega- 3 fatty acids intake with adiponectin have shown inconsistent results may be due to dietary diversity and genetic factors in each population. Therefore, further studies in a more various population may be required.
\end{abstract}

\section{Keywords adiponectin, obesity, omega-3 fatty acid, omega-6 fatty acid}

\section{Introduction}

Obesity is a global epidemic where more than 650 million people are obese worldwide. ${ }^{1}$ In Indonesia, there has been an increase in obesity by $47.2 \%$ in the last five years. An estimated 50 trillion rupiah per year is spent on the costs of treating obesity and its subsequent complications such as T2DM, heart disease, stroke, metabolic syndrome, and

\footnotetext{
Corresponding author:

dr. Helena Fabiani

Department of Nutrition, Faculty of Medicine, Universitas

Indonesia

Jl. Salembar Raya no.6, Central Jakarta, Indonesia

Email:dr.helenafabiani@gmail.com
}

atherosclerosis. ${ }^{2,3}$ Obesity occurs when there is an imbalance between the amount of input energy compared with the amount of energy that excreted in a long time. Western diet and sedentary lifestyle in today's lifestyle is one of the factors that cause an increase in obesity. In addition to physical activity, modification of dietary patterns is also essential for the prevention of obesity. ${ }^{4-6}$

Prolonged overnutrition provokes adipocytes expansion resulting in adipocytes dysfunction, which is characterized by the increase of tumor necrosis factor (TNF) $-\alpha$ and interleukin (IL) -6 , monocyte chemoattractant protein (MCP) -1, leptin, 
and resistin. This condition prompts the accumulation of immune cells within fat or adipose tissue and chronic low-level inflammation., ${ }^{4,8}$ Unlike other adipokines, which increase in obesity, the production of adiponectin is decreasing. Adiponectin is the most adipokines produced by adipocyte cells which have the effect of increasing insulin sensitivity, fatty acid oxidation, antiinflammatory, and antiaterogenic. ${ }^{9}$ Adiponectin is one indicator of the progression of obesity and its related diseases. ${ }^{10}$ Decreased production and secretion of adiponectin have even begun occuring in overweight conditions and once uncontrolled will worsen the obesity advancement. ${ }^{11}$

Dietary patterns of fatty acids intake within omega-3 and omega- 6 can also affect adiponectin levels. ${ }^{4,12,13}$ It is worth-mentioning that fatty acids within omega-3 and omega- 6 fatty are essential to hold different roles with each other to adiponectin. In contrast to fatty acid within omega-3 which constitutes anti-inflammatory effects, the one that of omega-6 genuinely form an intertwined effect of proinflammation. ${ }^{14}$ Due to these two fatty acids compete with one another in metabolic processes, the intake ratio of fatty acid within omega- 6 towards one that of omega-3 shall be maintained optimally. In contrast, in the present age of industrialization, unhealthy dietary patterns cause this ratio to become unbalanced. ${ }^{15}$ The role of the ratio between fatty acid in omega- 6 towards one that of omega- 3 in obesity, particularly in adiponectin, has not been put forward up to this point. Thus, this research aims to investigate the mechanism and the role of the intake ratio in omega- 6 fatty acid towards the one that of omega-3 in adiponectin as an indicator of obesity advancement and its related diseases.

\section{Discussion}

\section{Omega-3 and omega-6 fatty acids compete each other inside the body}

The investigation of fatty acids in the diet was commenced in 1929 by Burr when it was concluded that fatty acids in omega- 3 are essential elements to prevent disease. Research on fatty acids continues to grow to date, particularly over its integral role in preventing and curing different types of diseases. ${ }^{16}$ Omega- 6 and omega-3 possess essential elements called polyunsaturated fatty acids (PUFAs); such acids are obtained from the diet. Furthermore, fatty acids within omega- 6 are commonly identified as

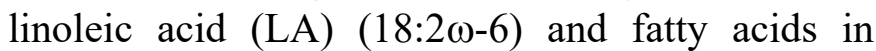
omega-3 fatty are generally termed as alpha-

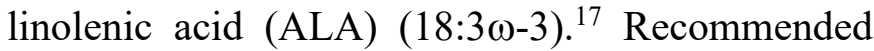
dietary allowance of omega-3 fatty acid from Institute of Medicine (IOM) for male and female adults are 1,6 g/day and 1,1 g/day, respectively. While omega- 6 fatty acid daily requirement is 17 g/day for male and $12 \mathrm{~g} /$ day for female. ${ }^{18}$ Food sources that contain ALA the most obtained from fish, seafood, fish oil, different combinations of nuts and seeds including flaxseed and chia seed. Some fortified foods, such as meat and eggs, are also a source of ALA. While LA is found in many types of vegetable oils and their products (Table 1). ${ }^{19,20}$

Both fatty acids will go through the metabolization process into long-chain fatty acids (LCFA) (20 and 22 carbon atoms) through the process of elongation (by adding two carbon atoms) and desaturation (through the addition of a double bond in between two carbon atoms) (Figure 1). Later, LA will be converted to arachidonic acid (AA) $(20: 4 \omega-6)$, while ALA will go through conversion into eicosapentaenoic acid (EPA) (20:5 $\omega-3)$ and docosahexaenoic acid (DHA) $(22: 6 \omega-3) .{ }^{15}$ Modifications of ALA into EPA and DHA occur are time-consuming processes as the cost of competing acids between LA and ALA in absorbing enzymes throughout the desaturation process; this desaturase enzyme is concealed by the fatty acid desaturase (FADS) gene. This enzyme is more likely to be used by ALA than LA. However, high LA intake, as in the Western diet, can disrupt desaturation and elongation from ALA. ${ }^{17}$

\section{The balance of omega- 6 fatty acid intake ratio towards omega-3 fatty acid}

Fatty acids within omega- 6 and omega- 3 cannot be substituted with each other and have metabolic and functional differences. Both ALA and AA will produce eicosanoids as the final product that has the opposite effect. Eicosanoids, which are derived by AA, contribute to inflammatory diseases, including obesity and its complications. High diets in omega6 fatty acids cause a pro-inflammatory, prothrombotic, and proagregatory state, with 
increased blood viscosity, vasospasm, vasoconstriction, and cell proliferation. On the other hand, ALA-derived eicosanoids have less potent inflammatory properties than AA-derived derivatives. ${ }^{7,17}$ The presence of competition in the use of enzymes in metabolic processes and end products that have opposite effects prompts a balance between the intake of these two fatty acids to be necessary. The recommended intake for omega- 6 to omega- 3 fatty acid ratio is $1-4: 1$. This ratio balance must be maintained optimally for the metabolic processes in the body to run normally. ${ }^{15}$

Before the era of food industrialization in the 20th century, researchers predicted that the ratio of fatty acids in omega- 6 fatty towards those that of omega-3 in human food averaged between 1:1 and $4: 1$. Along with the development of modern agricultural technology, there is a change in eating patterns manifested by the emergence of various processed foods. This shift in dietary patterns causes the ratio of fatty acid intake within omega- 6 towards one that of omega- 3 to experience a drastic change and reaches the highest ratio of all time, as such estimated to stand between 10:1 and 20:1, possibly even higher. ${ }^{17}$ The imbalance in the fatty acid intake ratio of Omega- 6 towards one within Omega-3 is predicted to contribute to a surge of overweight and obesity prevalences toward adults in various populations. $^{7}$

\section{The ratio of omega- 6 fatty acid intake towards omega-3 and its effect on adiponectin}

In the case of obesity, fatty acids within omega-3 and omega- 6 play an integral role in impacting adiponectin production and secretion. Adipocyte dysfunction that occurs upon obesity chronically prompts a state of low-grade inflammation indicated by multiple inflammatory markers and adipokines inlcuding leptin and resistin. This inflammatory state also causes dysregulation of adiponectin. ${ }^{7,8,21}$ Adiponectin (Acrp30/ADIPOQ) refers to a protein comprised of 244 amino acids with a $30 \mathrm{kDa}$ load concealed by adipocytes. Adiponectin commonly tasked to increase glucose uptake, insulin sensitivity, and oxidation within cells' fatty acids through two primary receptors; adiponectin receptor 1 (AdipoR1) and adiponectin receptor 2 (AdipoR2). ${ }^{22,23}$ Low adiponectin levels are associated with a higher risk of obesity and disease related to obesity. Conversely, high adiponectin levels work by elevating insulin sensitivity and oxidation with fat to prevent obesity and its complications. Adiponectin has been widely used as an examination indicator in monitoring the development and treatment of obesity. ${ }^{21}$ In adiponectin, fatty acids of omega- 3 and omega- 6 perform differently through several mechanisms, particularly the process of adipogenesis, fat homeostasis, endocannabinoid, and systemic inflammation (Table 2). Therefore, the balance of the ratio between fatty acids in omega- 6 and those of omega- 3 essential with adiponectin. ${ }^{3,7}$

In the process of adipogenesis and fat metabolism, fatty acids within omega- 6 and omega3 perform as transcriptional factors to control the gene expression involved within the process of diversification of preadipocytes. Differentiation of preadipocytes into mature adipocytes is a vital process in the advancement of obesity. High levels of exogenous fat will fill fat particles in mature adipocytes. Mature adipocytes can no longer divide, resulting in hypertrophy and hyperplasia that induces adipocyte dysfunction in excess energy. Eicosanoid derivatives of omega- 6 fatty acids, such as cyclooxygenase (COX), lipoxygenase (LOX), and prostacyclin are bound to prostacyclin receptors (IP-R) on the periphery of preadipocyte cells. Later the protein kinase A (PKA) pathway will be activated, which ultimately rules the expression of various peroxisome proliferators-activated receptors (PPARs) and results to adipogenesis. ${ }^{7,15,24}$

Arachidonic acid metabolites such as prostaglandin (PG) I2 and PGF2 generate an increase in white adipose tissue and a downfall in brown adipose tissue. In contrast, ALA works to repress the adipogenic effects of LA through several mechanisms. The expression of COX2 messenger ribonucleid acid (mRNA) and the production of COX2 have been evidently inhibited by DHA. Later, EPA and DHA also work to obstruct the activity of COX1 and COX2. Prostaglandin effects emanating from AA-derived eicosanoids are also directly inhibited by ALA. ${ }^{7,15,24}$ Lastly, EPA and DHA can minimize the production of cyclic adenosine $3^{\prime}, 5^{\prime}-$ monophosphate (cAMP) or PKA catalyst subunits in the IP-R pathway. Aside from this inhibitory effect within adipogenesis, fatty acids of omega-3 also 
alter lipid homeostasis by having the involved expression of genes suppressed in lipogenesis inclusive of fatty acid synthase, lipoprotein lipase and stearoyl-CoA desaturase-I and also increases the genes expression within $\beta$-oxidation including acylCoA oxidase. The result is a reduction in body fat mass, especially in the liver, skeletal muscle, and adipose tissue. ${ }^{24}$ In adipose tissue, there is an improvement in adipocyte function which will affect increasing the production and secretion of adiponectin. ${ }^{13}$

Other potential impacts of fatty acids in omega- 3 and omega- 6 fatty toward adiponectin are also related to the fusion of the distinctive eicosanoids it produces. PGE2, PGI2, and tromboxan (TXA) 2 and 4-grouping leukotrienes (LT) B4 generated from omega-6 fatty acids are potent pro-inflammatory agent. In contrast, prostaglandins 3-grouping (PGE3, PGI3, and TXA3) and 5-grouping LTB5 formed from omega-3 fatty acids from the same enzyme are less pro-inflammatory. Also, the formation of $\mathrm{E}$ series of 5-LOX (E1 and E2) derived from EPA and resolvin, protectin, and maresin, which originated from DHA, has potent antiinflammatory characteristics. In animal studies, intake of omega-3 acids convincingly minimizes the expression of inflammatory markers including MCP-1, IL-6, interferon- $\gamma$ (IFN- $\gamma$ ), and plasminogen activator inhibitor-1 (PAI-1). In human subjects, high diets in omega-3 massively shrinking the omega- 6 ratio towards omega- 3 in plasma, reduce the circulation of c-reactive protein (CRP), IL-6, TNF- $\alpha$, MCP-1 levels, and the number of tissue macrophages adipose. Through the effect on decreasing the activation of these inflammatory markers, a balanced ratio of fatty acids in omega- 6 towards those of omega-3 can increase adiponectin secretion. ${ }^{7,15,17,24}$

The expression and the concealment of adiponectin are also directly modulated by fatty acids of omega-3. As commonly mentioned in vitro studies, it is known that EPA and DHA act as natural ligands from peroxisome proliferator-activated receptor $\gamma(\operatorname{PPAR} \gamma)$. PPAR $\gamma$ is recognized to be an important regulator of adiponectin gene transcription. However, in contrast to DHA, which stimulates adiponectin secretion via the PPAR $\gamma$ channel exclusively, EPA is understood to have other additional mechanisms that are still unknown.
This additional mechanism is thought to involve the activation of the 5' adenosine monophosphateactivated protein kinase (AMPK) enzyme in increasing adiponectin secretion. ${ }^{7,25}$

Appetite regulation and energy balance are also influenced by fatty acids in omega- 6 and omega-3. LA-derived endocannabinoid metabolism can stimulate appetite and lipogenesis in the liver through activation of its receptors in various tissues. While fatty acids within omega- 3 reduce the production of endogenous endocannabinoids or decrease the sensitivity of their receptors, and also induce the production of other anorexia oxygenic neuropeptide neuropeptides in the hypothalamus, which serves to suppress appetite and lead to decreased energy intake. The decrease in energy intake will result in improved adipocyte function which affects increasing adiponectin production and secretion. ${ }^{7,17}$

Several kinds of research examining the relationship between fatty acids in omega-3 and omega- 6 fatty toward adiponectin have been performed (Table 3). A study that involved 44 patients with dialysis, plasma adiponectin levels were found to be in progressive correlation with omega-3 fatty acids $(\mathrm{r}=0.58)$ and inversely related to fatty acids of omega- $6(\mathrm{r}=-0.64)$, both of which statistically significant $(p<0.01) .{ }^{27}$ A meta-analysis investigation inferred that intake of fatty acids in omega-3 particularly those obtained from high dose supplementation $(>2 \mathrm{~g})$ can boost the levels of adiponectin in prediabetes and T2DM patients. However, the heterogeneity of results in these studies is still very high. ${ }^{32}$ Yang et al. also, in his research on subjects with polycystic ovary syndrome, show increased levels of adiponectin $(p=0.002)$ after administration of omega-3 fatty acids with varying doses (900-4000 mg) compared with placebo. ${ }^{33}$ Similar results were also obtained by studies in non-alcoholic fatty liver disease (NAFLD) patients who were given capsules of fish oil whose containment embodies the benefit of EPA $182 \mathrm{mg}$ and DHA $129 \mathrm{mg}$ twice daily for three months showed a significant boost in adiponectin levels ( $p$ $<0.001) .{ }^{28}$

In contrast to the results of the studies above, an individual investigation deliberated by Sabour et al. show results that an absence of visible development was indicated in adiponectin levels within the 
regulation of fatty acids of omega-3 in 14 months timespan towards patients with spinal cord injury. ${ }^{29}$ Torres-Castillo et al., in his research on subjects aged $18-65$ years with $B M I \geq 18.5 \mathrm{~kg} / \mathrm{m} 2$, show that adiponectin levels showed a decreasing trend when the ratio of fatty acids intake between omega- 6 toward those of omega-3 was increased. However, this difference has not statistically significant $(p=0.061) .{ }^{12}$ The administration of high omega-3 diets for six months in T2DM patients also showed no contrasting difference compared to the control group. ${ }^{31}$ Studies on supplementing fatty acids in omega-3 with lifestyle modification for 12 weeks in female subjects with overweight also did not provide a significant increase in adiponectin levels compared to the control group. ${ }^{30}$ Identical findings were revealed by Jacobo-Cejudo et al. in his study of T2DM patients, where no significant difference in adiponectin levels was found after six months of supplementation towards fatty acids within omega3 when compared to placebo. ${ }^{31}$

Studies that examined the ratio of fatty acids intake in omega- 6 toward those of omega-3 with adiponectin levels have not been widely examined and show different results. The diversity of the population remains limited, whereas it is understood that one's environment strongly influences a person's dietary patterns. Each population has different characteristics of dietary patterns, including food sources within intake ratio of fatty acids between both omega- 6 and omega-3.,24 Population differences also affect the metabolic processes of these two types of fatty acids. The metabolism process of these fatty acids in omega- 3 and omega6 is acknowledged to be influenced by genetic variations of the FADS enzyme, which can provoke differences in the rate metabolism towards these fatty acids and the composition of those in plasma. ${ }^{35}$ The ADIPOQ gene polymorphism has also probably played a part in the various findings of these studies. Genetic variations of ADIPOQ may be influence different response of adiponectin gene to these two fatty acids. ${ }^{36}$ Interactions among genetic factors and dietary patterns in diverse populations will lead to someone's different risks against obesity seen from the level of adiponectin as an indicator. ${ }^{17}$

\section{Conclusion}

Fatty acids contained within omega- 3 and omega- 6 are essential compounds that have different functions from one another to adiponectin. Both types of fatty acids in omega-3 and omega- 6 perform an integral role in adiponectin through the process of adipogenesis, fat homeostasis, endocannabinoids, and systemic inflammation. The balanced ratio between these two fatty acids can increase adiponectin levels to hold prominence in the prevention of obesity and its underlying diseases. Previous researches that examined the ratio of fatty acids intake from omega-6 to omega-3 with adiponectin levels is still limited, and the results have not been consistent; this is considered to be prompted by dietary diversity and genetic factors in each population. Modification of omega- 6 to omega-3 fatty acid intake ratio on diet potentially against obesity through adiponectin regulation. However, further research on the relationship between the ratio of fatty acids intake from omega6 to omega-3 with adiponectin in a more diverse population is required. 


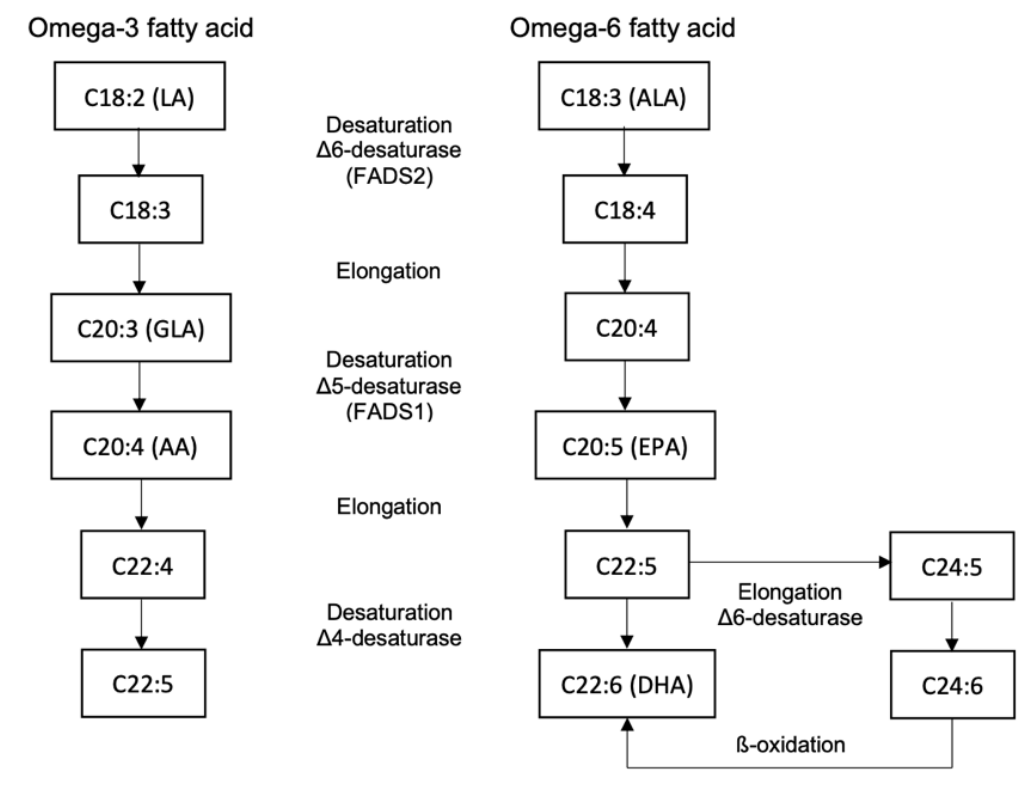

Figure 1. Desaturation and Elongation Process of Omega-3 and Omega-6 Fatty Acid ${ }^{15}$

Additional information: AA: arachidonic acid; ALA: alpha-linolenic acid; DHA: docosahexaenoic acid; EPA: eicosapentaenoic acid; FADS1: fatty acid desaturase 1; FADS2: fatty acid desaturase 2; GLA: gamma-linolenic acid; LA: linoleic acid.

Table 1. Omega-3 and omega-6 fatty acid food sources ${ }^{19,20}$

\begin{tabular}{lclc}
\hline Omega-3 Food Sources (per & $\begin{array}{c}\text { Fatty Acid } \\
\text { Content }(\mathrm{g})\end{array}$ & $\begin{array}{l}\text { Omega-6 Food Sources (per } \\
\text { 100 grams) }\end{array}$ & $\begin{array}{c}\text { Fatty Acid } \\
\text { Content }(\mathrm{g})\end{array}$ \\
\hline Flax seed & 6.4 & Sunflower oil & 65.7 \\
Chia seed & 4.9 & Sesame oil & 41.3 \\
Mackerel & 2.299 & Corn oil & 53.52 \\
Salmon & 1.966 & Canola oil & 19.63 \\
Herring & 1.571 & Peanut & 17.192 \\
Sardine & 1.43 & Pistachios & 13.485 \\
Cauliflower & 1.07 & Safflower oil & 12.724 \\
Mussel & 0.441 & Almond & 12.061 \\
Catfish & 0.38 & Palm oil & 9.5 \\
Brocolli & 0.258 & Margarine & 9.1 \\
Cod & 0.184 & Walnut & 7.782 \\
Eel & 0.147 & Tofu & 4.339 \\
Shrimp & 0.138 & Chicken & 2.96 \\
Clam & 0.107 & Tempeh & 2.518 \\
Yellowfin tuna & 0.1 & Chicken egg & 2.25 \\
Tilapia & 0.091 & Butter & 2.17 \\
\hline
\end{tabular}


Table 2. The role of omega- 6 and omega-3 fatty acids to adiponectin ${ }^{7,15}$

\begin{tabular}{|c|c|c|}
\hline Mechanism & Omega-6 Fatty Acid & Omega-3 Fatty Acids \\
\hline Adipogenesis & $\begin{array}{l}\text { - COX activates the PKA pathway } \\
\text { - COX and LOX Increase PPAR } \\
\text { gene expression leading to } \\
\text { adipogenesis }\end{array}$ & $\begin{array}{l}\text { - Reducing mRNA expression and } \\
\text { COX-2 production } \\
\text { - Restrains the effect of omega- } 6 \\
\text { fatty acid metabolites directly } \\
\text { - Reducing the production of cAMP } \\
\text { or PKA subunits }\end{array}$ \\
\hline Fat metabolism & - Increase triglyceride content & $\begin{array}{l}\text { - Decreases gene expression } \\
\text { associated with lipogenesis } \\
\text { - Increases genes expression of } \\
\text { oxidation- } \beta \text { related }\end{array}$ \\
\hline Inflammation & $\begin{array}{l}\text { - Increase the production of } \\
\text { inflammatory markers }\end{array}$ & - Prevents inflammation \\
\hline Endocannabinoid & - Increase appetite and energy intake & 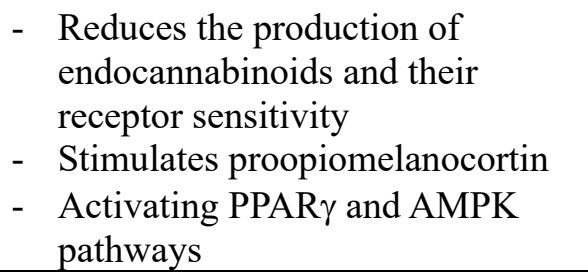 \\
\hline
\end{tabular}

Additional information: AMPK: 5' adenosine monophosphate-activated protein kinase; cAMP: cyclic adenosine 3',5'-monophosphate; COX: cyclooxygenase; LOX: lipoxygenase; mRNA: messenger ribonucleic acid; PKA: protein kinase A; PPAR: peroxisome proliferators-activated receptor; PPAR $\gamma$ : peroxisome proliferator-activated receptor $\gamma$.

Table 3. Characteristics of the studies that examined omega-3 and omega- 6 fatty acids with adiponectin

\begin{tabular}{|c|c|c|c|}
\hline Author & Study Design & Subjects & Results/Conclusion \\
\hline $\begin{array}{l}\text { An et al., } \\
2011^{27}\end{array}$ & $\begin{array}{l}\text { Cross-sectional } \\
\text { study }\end{array}$ & $\begin{array}{l}73 \text { dialysis patients and } \\
10 \text { healthy subjects }\end{array}$ & $\begin{array}{l}\text { Plasma adiponectin was associated } \\
\text { with erythrocyte omega- } 3 \text { fatty acid } \\
(\mathrm{r}=0.581, \mathrm{p}=0.023) \text { and inversely } \\
\text { associated with omega- } 6 \text { fatty acid } \\
(\mathrm{r}=-0.640, \mathrm{p}=0.010) \text { in the dialysis } \\
\text { patients }\end{array}$ \\
\hline $\begin{array}{l}\text { Qin et al., } \\
2015^{28}\end{array}$ & $\begin{array}{l}\text { Double-blind, } \\
\text { randomized } \\
\text { clinical trial }\end{array}$ & $\begin{array}{l}80 \text { NAFLD associated } \\
\text { with hyperlipidemia } \\
\text { patients; trial group }=40, \\
\text { control group }=40\end{array}$ & $\begin{array}{l}\text { Administration of fish oil capsules } \\
\text { (EPA } 182 \mathrm{mg} \text {; DHA } 129 \mathrm{mg} \text { ) twice } \\
\text { daily in } 12 \text { weeks showed increased } \\
\text { levels of adiponectin compared with } \\
\text { control group }(\mathrm{p}<0.001)\end{array}$ \\
\hline $\begin{array}{c}\text { Sabour et al., } \\
2015^{29}\end{array}$ & $\begin{array}{l}\text { Double-blind, } \\
\text { randomized } \\
\text { clinical trial }\end{array}$ & $\begin{array}{l}104 \text { spinal cord injury } \\
\text { patients; trial group }=54 ; \\
\text { control group }=50\end{array}$ & $\begin{array}{l}\text { No significant differences in } \\
\text { adiponectin between groups after } \\
\text { administration of omega-3 fatty acids } \\
\text { capsules (DHA } 465 \mathrm{mg} \text {; EPA } 63 \mathrm{mg} \text { ) } \\
\text { for } 14 \text { months }\end{array}$ \\
\hline $\begin{array}{l}\text { Balfegò et al., } \\
2016^{30}\end{array}$ & $\begin{array}{l}\text { Double-blind, } \\
\text { randomized } \\
\text { clinical trial }\end{array}$ & $\begin{array}{l}35 \text { T2DM patients; trial } \\
\text { group }=19, \text { control } \\
\text { group=16 }\end{array}$ & $\begin{array}{l}\text { No significant difference in } \\
\text { adiponectin between groups after } \\
\text { administration of high omega-3 diets } \\
\text { for } 6 \text { months }\end{array}$ \\
\hline
\end{tabular}


Table 3. Characteristics of the studies that examined omega-3 and omega- 6 fatty acids with adiponectin (continued)

\begin{tabular}{|c|c|c|c|}
\hline Author & Study Design & Subjects & Results/Conclusion \\
\hline $\begin{array}{l}\text { Jacobo- } \\
\text { Cejudo et al., } \\
2017^{31}\end{array}$ & $\begin{array}{l}\text { Single-blind, } \\
\text { randomized } \\
\text { clinical trial }\end{array}$ & $\begin{array}{l}54 \text { T2DM patients; trial } \\
\text { group=29; control } \\
\text { group }=25\end{array}$ & $\begin{array}{c}\text { No significant differences in } \\
\text { adiponectin between groups after } 6 \\
\text { months of administration of } 520 \mathrm{mg} \text { fish } \\
\text { oil capsules ( } 320 \mathrm{mg} \text { EPA; } 200 \mathrm{mg} \\
\text { DHA) }\end{array}$ \\
\hline $\begin{array}{l}\text { Torres- } \\
\text { Castillo et al., } \\
2018^{12} \\
\end{array}$ & $\begin{array}{c}\text { Cross-sectional } \\
\text { study }\end{array}$ & 170 healthy subjects & $\begin{array}{l}\text { No significant differences in } \\
\text { adiponectin between groups based on } \\
\text { tertiles of dietary omega- } 6 / 3 \text { ratio }\end{array}$ \\
\hline $\begin{array}{c}\text { Becic et al., } \\
2018^{32}\end{array}$ & $\begin{array}{l}\text { Systematic } \\
\text { review, meta- } \\
\text { analysis }\end{array}$ & $\begin{array}{l}10 \text { studies involved } 489 \\
\text { prediabetes and T2DM } \\
\text { patients; trial group }=251 \text {, } \\
\text { control group }=238\end{array}$ & $\begin{array}{l}\text { Administration of high dose }(>2 \mathrm{~g}) \text { in } \\
\geq 12 \text { weeks showed increased levels of } \\
\text { adiponectin compared with control } \\
\text { group }(\mathrm{p}<0.00001)\end{array}$ \\
\hline $\begin{array}{c}\text { Yang et al., } \\
2018^{33}\end{array}$ & $\begin{array}{l}\text { Systematic } \\
\text { review, meta- } \\
\text { analysis }\end{array}$ & $\begin{array}{l}3 \text { studies involved } 190 \\
\text { PCOS patients; trial } \\
\text { group }=103 \text {, control } \\
\text { group }=87\end{array}$ & $\begin{array}{l}\text { Administration of omega- } 3 \text { fatty acid } \\
(900-4000 \mathrm{mg}) \text { in } 6-12 \text { weeks showed } \\
\text { increased levels of adiponectin } \\
\text { compared with control group }(\mathrm{p}=0.002)\end{array}$ \\
\hline $\begin{array}{l}\text { Sedláček et } \\
\text { al., } 2018^{34}\end{array}$ & $\begin{array}{l}\text { Parallel-group } \\
\text { randomized } \\
\text { clinical trial }\end{array}$ & $\begin{array}{l}34 \text { overweight women; } \\
\text { LSM \& omega-3 } \\
\text { group }=11 ; \text { LSM } \\
\text { group }=10 ; \text { control } \\
\text { group }=8\end{array}$ & $\begin{array}{c}\text { No significant differences in } \\
\text { adiponectin between groups after } \\
\text { administration of omega-3 with LSM } \\
\text { for } 12 \text { weeks }\end{array}$ \\
\hline
\end{tabular}

\section{Conflict of Interest}

Authors declared no conflict of interest regarding this article.

\section{Open Access}

This article is distributed under the terms of the Creative Commons Attribution 4.0 International Licence

(http://creativecommons.org/licenses/by/4.0/), which permits unrestricted use, distribution, and reproduction in any medium, provided you give appropriate credit to the original author(s) and the source, provide a link to the Creative Commons license, and indicate if changes were made.

\section{References}

1. WHO. Obesity and overweight [Internet]. 2018 [cited 2019 Oct 20]. Available from: https://www.who.int/news-room/fact- sheets/detail/obesity-and-overweight

2. Wulansari A, Mardiana D, Baliwati Y. Kerugian ekonomi akibat biaya perawatan kesehatan langsung pada orang dewasa obesitas di Indonesia. Media Kesehat Masy Indones Univ Hasanuddin. 2016;12(4):20-215.

3. Farimani AR, Hariri M, Azimi-Nezhad M, Borji A, Zarei S, Hooshmand E. The effect of n-3 PUFAs on circulating adiponectin and leptin in patients with type 2 diabetes mellitus: a systematic review and metaanalysis of randomized controlled trials. Acta Diabetol. 2018;55(7):641-52.

4. Paniagua JA. Nutrition, insulin resistance and dysfunctional adipose tissue determine the different components of metabolic syndrome. World J Diabetes. 2016;7(19):483.

5. Alzeidan R, Rabiee F, Mandil A, Hersi A, Fayed A. Non-communicable disease risk factors among employees and their families of a Saudi University: An epidemiological study. PLoS One. 2016;11(11):1-13.

6. Kosaka S, Suda K, Gunawan B, Raksanagara A, Watanabe C, Umezaki M. Urban-rural difference in the determinants of dietary and energy intake patterns: A case study in west Java, Indonesia. PLoS One. 2018;13(5):1-18.

7. Wang L. Omega-3 and omega-6 fatty acids : Role in body fat gain and development of obesity. North Am J 
Med Sci. 2015;8(4):163-71.

8. Meiliana A, Dewi NM, Wijaya A. Adipose Tissue, Inflammation (Meta-inflammation) and Obesity Management. Indones Biomed J. 2015;7(3):129.

9. Torre-Villalvazo I, Bunt AE, Aleman G, Marques-Mota CC, Diaz-Villasenor A, Noriega LG. Adiponectin synthesis and secretion by subcutaneous adipose tissue is impaired during obesity by endoplasmic reticulum stress. J Cell Biochem. 2018;1-15.

10. Nigro E, Scudiero O, Monaco ML, Palmieri A, Mazzarella G, Costagliola C, et al. New insight into adiponectin role in obesity and obesity-related diseases. Biomed Res Int. 2014;2014:1-14.

11. Gariballa S, Alkaabi J, Yasin J, Al Essa A. Total adiponectin in overweight and obese subjects and its response to visceral fat loss. BMC Endocr Disord. 2019;19(1):1-6.

12. Torres-Castillo N, Silva-Gómez JA, Campos-Perez W, Barron-Cabrera E, Hernandez-Cañaveral I, GarciaCazarin M, et al. High dietary $\omega-6: \omega-3$ PUFA ratio is positively associated with excessive adiposity and waist circumference. Obes Facts. 2018;11(4):344-53.

13. Ostrowska L, Fiedorczuk J, Adamska E. Effect of diet and other factors on serum adiponectin concentrations in patients with type 2 diabetes. Rocz Państwowego Zakładu Hig. 2013;64(1):61-6.

14. Gray B, Steyn F, Davies PSW, Vitetta L. Omega-3 fatty acids: A review of the effects on adiponectin and leptin and potential implications for obesity management. Eur J Clin Nutr. 2013;67(12):1234-42.

15. Simopoulos AP, DiNicolantonio JJ. The importance of a balanced omega- 6 to omega- 3 ratio in the prevention and management of obesity. Open Hear. 2016;3(2):1-6.

16. Spector AA, Kim HY. Discovery of essential fatty acids. J Lipid Res. 2015;56(1):11-21.

17. Simopoulos AP. A high omega-6/ omega-3 fatty acids ratio increases the risk for obesity. Interv Obes Diabetes. 2018;1(2):28-39.

18. FAO. Fats and Fatty Acids in Human Nutrition. Vol. 91, Food Agriculture Organization Food and Nutrition Paper. Geneva; 2010.

19. Gallagher M. The nutrients and their metabolism. In: Mahan L, Escott-Stump S, Raymond J, editors. Krause's Food and Nutrition Care Proccess. 13th ed. Missouri: Elsevier; 2013. p. 50-6.

20. Gropper S, Smith J. Lipids. In: Gropper S, Smith J, editors. Advanced Nutrition and Human Metabolism. 6th ed. Australia: Wadsworth Cengage Learning; 2013. p. 138-40.

21. Ghoshal K. Adiponectin: Probe of the molecular paradigm associating diabetes and obesity. World $\mathrm{J}$ Diabetes. 2015;6(1):151.

22. Tumminia A, Vinciguerra F, Parisi M, Graziano M, Sciacca L, Baratta R, et al. Adipose tissue, obesity and adiponectin: Role in endocrine cancer risk. Int J Mol Sci. 2019;20(12).

23. van Andel M, Heijboer A, Drent M. Adiponectin and its isoform in pathophysiology. In: Makowski G, editor. Advances in Clinical Chemistry. 85th ed. Cambridge:
Elsevier; 2018. p. 117-24.

24. Dinicolantonio JJ, O'Keefe JH. Importance of maintaining a low omega-6/omega-3 ratio for reducing inflammation. Open Hear. 2018;5(2):3-6.

25. Song J, Li C, Lv Y, Zhang Y, Amakye WK, Mao L. DHA increases adiponectin expression more effectively than EPA at relative low concentrations by regulating PPAR $\gamma$ and its phosphorylation at Ser273 in 3T3-L1 adipocytes. Nutr Metab (Lond). 2017;14(1):1-11.

26. Simopoulos AP. An increase in the omega-6/omega-3 fatty acid ratio increases the risk for obesity. Nutrients. 2016;8(3):1-17.

27. An W, Son Y, Kim S, Kim K, Bae H, Lee S, et al. Association of adiponectin and leptin with serum lipids and erythrocyte omega- 3 and omega- 6 fatty acids in dialysis patients. Clin Nephrol. 2011;75(3):195-203.

28. Qin Y, Zhou Y, Chen SH, Zhao XL, Ran L, Zeng XL, et al. Fish oil supplements lower serum lipids and glucose in correlation with a reduction in plasma fibroblast growth factor 21 and prostaglandin E2 in nonalcoholic fatty liver disease associated with hyperlipidemia: A randomized clinical trial. PLoS One. 2015;10(7):1-13.

29. Sabour H, Javidan AN, Latifi S, Shidfar F, Heshmat R, Emami Razavi SH, et al. Omega-3 fatty acids' effect on leptin and adiponectin concentrations in patients with spinal cord injury: A double-blinded randomized clinical trial. J Spinal Cord Med. 2015;38(5):599-606.

30. Balfegò M, Canivell S, Hanzu FA, Sala-Vila A, Martínez-Medina M, Murillo S, et al. Effects of sardineenriched diet on metabolic control, inflammation and gut microbiota in drug-naïve patients with type 2 diabetes: A pilot randomized trial. Lipids Health Dis. 2016;15(1):1-11.

31. Jacobo-Cejudo MG, Valdés-Ramos R, GuadarramaLópez AL, Pardo-Morales RV, Martínez-Carrillo BE, Harbige LS. Effect of n-3 polyunsaturated fatty acid supplementation on metabolic and inflammatory biomarkers in type 2 diabetes mellitus patients. Nutrients. 2017;9(6):1-11.

32. Becic T, Studenik C. Effects of omega-3 supplementation on adipocytokines in prediabetes and type 2 diabetes mellitus: Systematic review and metaanalysis of randomized controlled trials. Diabetes Metab J. 2018;42(2):101-16.

33. Yang K, Zeng L, Bao T, Ge J. Effectiveness of Omega3 fatty acid for polycystic ovary syndrome: A systematic review and meta-analysis. Reprod Biol Endocrinol. 2018;16(1):1-13.

34. Sedláček P, Plavinová I, Langmajerová J, Dvořáková J, Novák J, Trefil L, et al. Effect of N-3 fatty acids supplementation during life style modification in women with overweight. Cent Eur J Public Health. 2018;26(4):265-71.

35. Brayner B, Kaur G, Keske MA, Livingstone KM. FADS polymorphism, omega-3 fatty acids and diabetes risk: A systematic review. Nutrients. 2018;10(6):1-11.

36. Alsaleh A, Sanders TAB, O'Dell SD. Effect of interaction between PPARG, PPARA and ADIPOQ 
gene variants and dietary fatty acids on plasma lipid profile and adiponectin concentration in a large intervention study. Proc Nutr Soc. 2012;71(1):141-53. 